\title{
NO PRINCÍPIO ERA A PALAVRA, MAS A PALAVRA FOI TRADUZIDA PARA OS SINAIS
}

\author{
Emerson Cristian Pereira dos Santos $\underline{1}$ \\ ${ }_{1}^{1}$ Universidade Federal do Ceará, Fortaleza, Ceará, Brasil
}

\begin{abstract}
Resumo: Além do que é considerado sacro pelas religiões judaico-cristãs, a Bíblia também está repleta de poesia, e sua tradução para a Libras pode nos ajudar a compreender de que maneira se constituem os repertórios de tradução no polissistema literário da cultura surda brasileira. Neste artigo, trago reflexões sobre a relação entre ideologia, tradução e literatura na formação de repertórios literários da cultura surda, a partir da tradução da Bíblia.
\end{abstract}

Palavras-chave: Bíblia; Libras; Literatura surda; Repertórios literários.

\section{IN THE BEGINNING WAS THE WORD, BUT THE WORD WAS TRANSLATED INTO SIGNS}

\begin{abstract}
In spite of what is considered sacred by the Judeo-Christian religions, the Bible is also filled with poetry, whose translation to Brazilian Sign Language (Libras) can help us understand in what ways the translation repertoires are formed in the literary polysystem of the Brazilian deaf culture. In this article, I shall reflect upon the relationship between ideology, translation and literature in that polysystem from the point of view of the translation of the Bible.
\end{abstract}

Keywords: Bible; LSB; Deaf literature; Literary repertoire. 


\section{Introdução}

Ao tentarmos uma busca da Bíblia em Libras, vamos ter grandes dificuldades de encontrarmos trabalhos sistemáticos - refiro-me a traduções que envolvam toda a Bíblia, não exclusivamente algumas narrativas dela. Até certo ponto essa carência é compreensível, primeiro porque, dentro do polissistema sociocultural brasileiro, o polissistema da cultura surda (literatura produzida em Libras, literatura traduzida para a Libras, contos, histórias, piadas, artes plásticas, musicalidade em sinais, politizações etc.) é muito jovem e periférico em relação ao da cultura ouvinte, e, de certa forma, tem chamado pouca atenção; depois porque estamos diante de um campo muito novo nos Estudos da Tradução no Brasil, ou seja, o da tradução de textos sensíveis para a Libras; em terceiro lugar, em virtude da modalidade espaço-visual da língua de sinais, um projeto de tradução de toda a Bíblia precisaria contemplar bons equipamentos de filmagem, edição e armazenamento em grande escala dos vídeos, espaço de postagem específico para publicação, manutenção desse espaço e um bom número de tradutores especializados na área. Em outras palavras, é um trabalho complexo, provavelmente até mais do que os que envolvem pares de línguas oral-auditivas. Por último, agregando tudo que foi dito à falta de patrocinadores, o resultado não poderia ser outro senão a escassez da Bíblia em Libras.

Acima, aplico o termo "polissistema" como Even-Zohar o usa em sua Teoria dos Polissistemas (Polysystem Theory), adotada neste trabalho para dar conta de refletir sobre algumas particularidades tradutórias envolvidas com os binômios cultura surda/ cultura ouvinte e texto sensível/texto literário. Com base em alguns pressupostos da teoria, meu objetivo principal neste artigo é iniciar uma discussão sobre a formação e a composição do jovem sistema literário da cultura surda, a partir da tradução do poético livro bíblico Cântico dos Cânticos para a Libras, na tentativa de entender como o sistema literário surdo influencia na seleção de repertórios e como os tradutores estão ajudando a criar e a moldar a iden- 
tidade do polissistema. A partir de uma perspectiva descritivista da tradução, minhas duas perguntas iniciais são as seguintes: (1) Como alguns repertórios (formas, estilos, ideias, ritmo, gêneros etc.) estão sendo estabelecidos no polissistema literário da cultura surda brasileira? (2) De que maneira os tradutores e suas traduções para a Libras estão ajudando a moldar esse polissistema?

Para responder às perguntas acima, utilizo a tradução de Cântico dos Cânticos para a Libras realizada pelo grupo religioso denominado Testemunhas de Jeová (TJ). Essa escolha não foi fortuita, e deu-se, em primeiro lugar, porque tanto o texto em língua portuguesa quanto sua tradução para a Libras possuem fortes características líricas, por isso são considerados poéticos. O segundo motivo está ligado ao fato de a tradução das $\mathrm{TJ}^{1}$ ter sido o único trabalho de tradução de Cântico para a Libras que encontrei disponível gratuitamente on-line para acesso e download. Em terceiro lugar, porque compreendo que o surgimento, o estabelecimento e o status de determinados repertórios de tradução têm muito a ver com relações filosófico-ideológicas de grupos ${ }^{2}$ culturais, religiosos, políticos etc. Como é possível presumir, as reflexões que surgirão no artigo ${ }^{3}$ partem da conexão entre tradução, texto literário e texto sensível a partir de Cântico dos Cânticos.

A seção 2 é dedicada a uma discussão sobre repertórios ideológicos envolvidos com a tradução. Na seção 3, apresento alguns pontos principais da Teoria dos Polissistemas. Na seção 4, reflito sobre alguns repertórios do polissistema literário da cultura surda.

\footnotetext{
${ }^{1}$ A propósito, por esta última razão, todos os versículos bíblicos citados neste artigo foram extraídos da Tradução do Novo Mundo da Bíblia Sagrada, revisão de 2015.

${ }^{2}$ As traduções para mais de 80 línguas de sinais realizadas por tradutores TJ de vários países evidenciam seguir, basicamente, o mesmo repertório de tradução.

${ }^{3}$ Sou muito grato ao professor Dr. Robert de Brose por me oferecer comentários e importantes contribuições neste trabalho.
} 


\section{A conexão entre texto sensível, tradução e ideologias}

Naturalmente, o objetivo dos grupos religiosos com a tradução da Bíblia é a evangelização dos povos, mas além de gêneros textuais como epistolares, jurídicos, proféticos, apocalípticos etc., o texto judaico-cristão também está repleto de poesia. No cânon utilizado pelos evangélicos, em geral, são poéticos os livros de Cântico dos Cânticos, Eclesiastes, Lamentações de Jeremias, Provérbios, Salmos e até mesmo Jó. No cânon dos católicos, além desses que citei, é possível classificar Eclesiástico e Sabedoria como livros poéticos. Diferentemente de outros da Bíblia, todos esses utilizam a linguagem para expressar - de modo peculiar e criativo - alegria, amor, ansiedade, desespero, dor, esperança, felicidade, medo, melancolia, paixão, saudade, enfim, sentimentos e emoções, usando recursos estilísticos diversos para produzir uma linguagem metafórica, imaginativa e poética. Em resumo, são livros repletos de lirismo e subjetividade que conduzem seus leitores a ambientes campestres, pastoris, palacianos, domésticos etc., e ao mundo da imaginação.

No Brasil, o status quo da Bíblia em língua de sinais tem dificultado o surgimento de pesquisas, teorizações e publicações sobre as possíveis negociações linguístico-culturais promovidas pelo tradutor entre sensibilidade textual e Libras/cultura surda. Mas o grupo religioso TJ, com congregações (salões) em vários países, possui o que pode ser hoje a mais sistemática e completa tradução da Bíblia para a Libras. Aliás, essa comunidade cristã já realizou traduções de boa parte dos livros bíblicos para mais de 80 línguas de sinais. Além disso, e apesar de ser uma atividade especificamente diferenciada da tradução, as interpretações para Libras de liturgias católicas e evangélicas realizadas por outros tantos profissionais de grupos religiosos distintos são comuns no Brasil. Por isso já é possível dizer que os tradutores de línguas oral-auditivas não estão mais sozinhos nessa via crucis. Para lhes fazer companhia nas Estações da Cruz, na Via Dolorosa, surge o tradutor e intérprete de Libras, não como Simão, o cirineu, uma vez que cada um já possui sua própria cruz para carregar, mas como alguém que também está com o peso 
das ideologias sobre os ombros, enquanto as costas ficam visivelmente expostas aos açoites do flagrum dogmático-religioso.

Ao utilizar as metonímias acima, quero dizer que embora a autoestima dos tradutores de textos sensíveis, em geral, não sofra constantes tentativas de provação promovidas pelo estético-poético, como geralmente ocorre com a dos tradutores literários, ela pode ser impiedosamente fustigada pelas ideologias, tanto pela do público-alvo quanto pela do público-fonte. Na tradução da Bíblia, onde o princípio norteador muito raramente é o mesmo que guiou a mão de Campos (2004 e 2000) ao traduzir poeticamente "Qohélet", o que sabe: poema sapiencial" e "Bere'shith": a cena da origem", os tradutores praticantes de dogmas religiosos correm o risco de serem acusados de heréticos e falsários, caso violem o princípio ideológico tacitamente domiciliado no pensamento religioso dos grupos abrangidos pela tradução. Essa última declaração não é inédita, nem a afirmação de que o que parece preceder boa parte das traduções da Bíblia como texto sensível são as ideologias, pelas quais as denominações judaico-cristãs estabelecem suas doutrinas e interpretam o mundo à sua volta.

Para trazer exemplos concretos sobre a estreita conexão das ideologias com as traduções de textos sensíveis e não ficar apenas em minhas alegações, em 2012, em um dos cursos de formação de tradutores e intérpretes promovidos pela Associação dos Profissionais Intérpretes e Tradutores de Libras do Ceará (APILCE), foi possível constatar empiricamente "uma mão oculta" conduzindo as mãos daqueles que traduziam para a Libras trechos da Bíblia em língua portuguesa, por meio de dados colhidos em vídeo em uma atividade de tradução, em uma disciplina sobre tradução de texto sensível que ministrei. A atividade solicitava aos cursistas a tradução dos trechos do quadro abaixo para a Libras. Os que participa-

4 "Qohélet" em hebraico, "Eclesiastes" em português.

5 "Bere'shith" em hebraico, "No princípio" em português.

${ }^{6}$ Robinson (2009) utiliza a metáfora da mão invisível em seu artigo The Invisible Hands that Constrol Translation. 
ram ou eram evangélicos da Igreja Batista Regular ou Testemunhas de Jeová ou Católicos, por isso, propositalmente, selecionei três passagens controversas, ou seja, divergentes quanto ao cânon adotado pelos grupos religiosos presentes na sala de aula, como mostram os trechos com os nossos grifos no quadro abaixo.

Quadro 1 - Versículos bíblicos em três traduções distintas (grifos meus).

\begin{tabular}{|c|c|c|c|}
\hline Versículos & $\begin{array}{l}\text { Edição } \\
\text { Contemporânea }^{7}\end{array}$ & $\begin{array}{l}\text { Tradução do } \\
\text { Novo Mundo } \\
\text { (Revisão de 1986) }\end{array}$ & Edição Pastoral $^{9}$ \\
\hline $\begin{array}{l}\text { Mat. 1: } \\
24,25\end{array}$ & $\begin{array}{l}\text { José, despertando } \\
\text { do sono, fez como o } \\
\text { anjo do Senhor lhe } \\
\text { ordenara, e recebeu a } \\
\text { sua mulher. } \\
\text { Mas não a conheceu } \\
\text { até que ela deu à luz } \\
\text { um filho. E ele lhe } \\
\text { pôs o nome de Jesus. }\end{array}$ & $\begin{array}{l}\text { José, acordando do } \\
\text { sono, fez conforme } \\
\text { o anjo de Jeová lhe } \\
\text { indicara e levou } \\
\text { sua esposa para } \\
\text { casa. Mas não teve } \\
\text { relaçôes com ela até } \\
\text { ela ter dado à luz } \\
\text { um filho; e deu-lhe } \\
\text { o nome de Jesus. }\end{array}$ & $\begin{array}{l}\text { Quando acordou, } \\
\text { José fez conforme } \\
\text { o Anjo do Senhor } \\
\text { havia mandado: } \\
\text { levou Maria para } \\
\text { casa, e, sem ter } \\
\text { relações com ela, } \\
\text { Maria deu à luz um } \\
\text { filho. E José deu } \\
\text { a ele o nome de } \\
\text { Jesus. }\end{array}$ \\
\hline Lucas 23:43 & $\begin{array}{l}\text { Respondeu-lhe Jesus: } \\
\text { Em verdade te digo } \\
\text { que hoje estarás } \\
\text { comigo no paraíso. }\end{array}$ & $\begin{array}{l}\text { E ele lhe disse: } \\
\text { "Deveras, eu te } \\
\text { digo hoje: Estarás } \\
\text { comigo no Paraíso." }\end{array}$ & $\begin{array}{l}\text { Jesus respondeu: } \\
\text { Eu lhe garanto: } \\
\text { hoje mesmo você } \\
\text { estará comigo no } \\
\text { paraíso. }\end{array}$ \\
\hline João 1:1 & $\begin{array}{l}\text { No princípio era o } \\
\text { Verbo, e o Verbo } \\
\text { estava com Deus, e o } \\
\text { Verbo era Deus. }\end{array}$ & $\begin{array}{l}\text { No princípio era a } \\
\text { Palavra, e a Palavra } \\
\text { estava com o Deus, } \\
\text { e a Palavra era [um] } \\
\underline{\text { deus. }}\end{array}$ & $\begin{array}{l}\text { No começo a } \\
\text { Palavra já existia: } \\
\text { a Palavra estava } \\
\text { voltada para Deus, } \\
\text { e a Palavra era } \\
\underline{\text { Deus. }}\end{array}$ \\
\hline
\end{tabular}

Fonte: Elaborado pelo autor.

7 Adotada por Igrejas Evangélicas, entre elas estão as mais conservadoras, as pentecostais e as neopentecostais.

${ }^{8}$ Adotada pelas Testemunhas de Jeová.

${ }^{9}$ Adotada pela Igreja Católica Apostólica Romana. 
Cada cursista deveria escolher as três passagens bíblicas (Mateus 1: 24,25; Lucas 23: 43; João 1:1) e realizar sua tradução para a Libras. O principal objetivo era verificar de que forma os princípios ideológicos (a mão oculta) subjacentes à atividade tradutória conduziriam a tradução do texto sensível, a começar pela escolha dos trechos, ou seja, como cada passagem acima de cada Bíblia adotada pelos grupos sugere um entendimento particular, então cada tradutor elegeu o fragmento que estava em harmonia com seus preceitos doutrinários, com seus dogmas religiosos. Fazendo assim, os que traduziam não penalizariam sua consciência por terem adotado uma postura diferente daquela pela qual sua doutrina religiosa compreende o mundo. Os dados evidenciaram que, de modo geral, tradutores de Libras praticantes de doutrinas religiosas não estão meramente preocupados em traduzir os sistemas linguísticos envolvidos com o texto sensível, mas também concentrados em cumprir com a tradição dogmática estabelecida por seus grupos religiosos a partir da interpretação da Bíblia sob sua óptica. Dito de outra forma: na tradução de textos sensíveis realizada por praticantes de dogmas religiosos há leis implícitas ligadas a ideologias conciliando atividade tradutória a doutrinas. Isso porque qualquer negociação linguístico-cultural desajustada das concepções de um determinado grupo tem um grande potencial de ainda ser considerada por seus pares, ou pela consciência, uma transgressão da Palavra de Deus.

Recupero o clássico exemplo de Sofrônio Eusébio Jerônimo (345?-419/420), meses após ele ter traduzido a Bíblia do Hebraico e do Grego para o Latim, quando foi acusado de herético em virtude de suas negociações linguísticas. Em um excerto de uma de suas muitas correspondências enviadas a Jerônimo, Agostinho (354-430/431) trata da inquietação que a tradução de Jerônimo causou nos fieis, quando um bispo a introduziu na igreja sob sua responsabilidade. À medida que a congregação percebia trechos no livro do profeta Jonas nada familiares diante do que já estavam acostumados a ouvir, os protestos vieram em seguida, inclusive os gregos manifestaram indignação sobre a alegada falsificação das 
Escrituras, não poupando seu tradutor e dando-lhe o epíteto de profano. Como a situação não se resolvia, pelo contrário, cada vez mais se agravava, o bispo resolveu consultar os judeus a fim de resolver o problema, mas "eles responderam, ou por ignorância ou por malícia, que os manuscritos Hebreus continham exatamente o que podia ser encontrado nos manuscritos grego e latino". Encurralado, e "para escapar do grande perigo" e não perder todos os fieis, a saída do bispo foi retratar-se e dizer que havia cometido um erro ao introduzir a tradução de Jerônimo na congregação (LEFEVERE, 1992, p. 2-3).

Outro infortúnio que ecoou pelos séculos, e que publicações sobre tradução de textos sensíveis dificilmente deixam de citar, ocorreu entre Martinho Lutero (1483-1546) e lideranças religiosas católicas coetâneas que ainda sofriam as consequências do ocaso medieval e estavam desnorteadas mesmo algum tempo após o alvorecer da Renascença, momento de rupturas não só de ordem artística, mas também científicas, filosóficas, políticas, culturais e religiosas, onde o pensamento e o empreendimento em ser livres das dominações eram insistentes. Pouco tempo depois de utilizar a porta da Igreja do Castelo de Wittenberg (Alemanha) para pendurar suas 95 teses, o ícone principal da Reforma Protestante despertaria mais um incômodo nas autoridades religiosas ao "acrescentar", em sua tradução para o Alemão, a palavra "somente " ao versículo 28 do terceiro capítulo da Epístola de Paulo aos Romanos. O mal-estar diante das acusações de heresia até rendeu uma Carta Aberta sobre a Tradução em 1530. Nela, Lutero (2010, p. 97) não só se defende como contra-ataca seus algozes "papistas", usando desde palavras como "mentirosos", "embusteiros" e "asnos" a expressões como "[...] eles ainda têm orelhas muito longas e seu zurro é muito fraco para julgar minha tradução".

Evidentemente, não vou entrar no mérito da discussão se era uma condição sine qua non acrescentar ou excluir a palavra "somente" do versículo mencionado acima, porque o que julgo mais essencial para este momento de reflexão no artigo não é entrar nessa dança das cadeiras, mas demonstrar que aquele embate entre 
o fazer permanecer e o retirar a palavra em questão deixa a céu aberto os interesses ideológicos envolvidos com a tradução: por um lado, sugerindo uma possível perspectiva da Igreja, se a tradução propõe que o homem é salvo "somente" pela fé, onde fica a intercessão sacerdotal em favor daqueles que estariam no purgatório? Por outro, agora sugerindo uma possível óptica do pensamento reformista, se a tradução "acrescentar" a palavra "somente", isso pode ser mais um recurso na tentativa de enfraquecer o poder privilegiado e a intolerância da Igreja. A propósito, sola fide (somente pela fé) foi apenas um dos cinco princípios religiosos pelos quais os reformadores estabeleceram sua teologia contra boa parte do credo Católico Apostólico Romano. Além dela, as outras quatro expressões latinas que resumem o pensamento teológico reformista são: sola gratia (somente a graça), sola scriptura (somente a Escritura), soli Deo glória (glória somente a Deus) e solus Christus (somente Cristo). O fato é que, se bem observado, o apagamento ou a manutenção da palavra na tradução mexe com ideologias, desembocando em um dos principais dogmas religiosos: o do purgatório.

Lutero e Jerônimo, por um motivo ou por outro, romperam o cânone da tradição tradutória, e como a tradição naqueles casos estava ligada diretamente a ideologias religiosas, os dois tradutores inevitavelmente se viram diante de encurralamentos tradutório-ideológicos. No entanto, para não quebrar a régua do cânone, tradutores de textos sensíveis tendem a seguir a ideologia do sistema religioso ao qual pertencem. Neste ponto, trago aqui uma observação da tradução pelas TJ da Bíblia para a Libras, em João $1: 1$. O versículo em língua portuguesa diz o seguinte: "No princípio era a Palavra, e a Palavra estava com Deus, e a Palavra era um deus". Observe que o uso de "D" e "d" e a presença do artigo indefinido "um" sugerem uma relação de hierarquia entre "Deus" e "um deus/Palavra". Na tradução para a Libras, essa relação de hierarquia e de independência entre "Deus" e "um deus" não só é mantida como é mais evidente ainda, e foi construída da seguinte maneira: o sinal ligado a "Deus" (configuração de mão em D) é feito no espaço do lado superior direito, bem à cima do ombro do 
tradutor, e o sinal que está ligado à expressão "um deus" (também com configuração de mão em D) é executado do lado esquerdo, mas nitidamente as posições entre este último e o outro são assimétricas, ou seja, o que é ligado a "Deus" está em uma posição mais acima, e o que se refere a "um deus", embora do outro lado, está mais abaixo. Ora, como no texto-fonte esses conceitos são feitos com iniciais maiúsculas e minúsculas e com o uso do artigo indefinido "um", e em Libras essas estratégias não seriam possíveis, a tradução explorou outros recursos a fim de seguir a tradição religiosa e deixar claro que "Deus" e "um deus" são, entre outras coisas, hierarquicamente diferentes.

Sob outra perspectiva, o grande cuidado em cumprir com a tradição estimula o tradutor a incluir na língua de chegada significados não explícitos na língua de partida. Grosso modo, isso é conhecido como explicitação, na Teoria da Relevância. Retomando a tradução para a Libras de João 1:1, ao realizar o sinal PODER, o tradutor relaciona-o tanto a "Deus" como a "um deus", mas ao executar o sinal PODER ligado a "Deus" a expressão facial é muito mais intensa do que o sinal PODER associado a "um deus", embora o tradutor depois realize o sinal IGUAL. O fato é que não há qualquer referência ao conceito PODER no versículo do texto-fonte, ou qualquer orientação que justifique o motivo do uso da expressão facial intensificada na tradução para a Libras. Essas informações explicitadas principalmente por meio da expressão facial estão ligadas a um conjunto de leis regidas pelo entendimento dogmático a partir da interpretação de outros versículos bíblicos pelo grupo religioso. Por exemplo, essas informações podem decorrer de João, 14:28: "[...] vou para o Pai, pois o Pai é maior do que eu" - um dos princípios doutrinários para as TJ. Portanto, nesses casos, as explicitações podem ser compreendidas como o resultado de preocupações em cumprir com a tradição dogmático-religiosa.

Os dados empíricos acima evidenciam que o conjunto de leis por trás da tradução possui uma forte influência no desenvolvimento de repertórios a serem adotados pelos tradutores, estabelecendo, tacitamente, uma tradição tradutória a ser seguida por qualquer 
um que compartilhe do mesmo entendimento dogmático-religioso. Na tradução de João 1:1 para a American Sign Language (ASL), a Língua de Sinais Americana, o mesmo princípio é praticado pelo tradutor americano TJ. Este, assim como o brasileiro, estabelece uma correspondência de hierarquia entre "God" e "a god", como no texto-fonte, mas intensificada pelas expressões faciais. Essa mesma observação pode ser feita com relação à tradução para a Lengua de Señas Argentina, realizada por tradutores argentinos TJ. Obviamente, é mais do que possível que os repertórios das primeiras traduções feitas por um determinado grupo de tradutores TJ, de uma determinada nacionalidade, tenham servido como modelo para as traduções que se seguiram. Dito de outra forma, a tradição foi estabelecida. Mas é possível constatar que, no caso da Bíblia, o princípio dogmático-ideológico é o regente do cânon, fazendo os tradutores seguirem um repertório específico, e não outro.

Diante do que foi dito acima, é possível dizer que, em língua de sinais, um olhar atento do pesquisador para as expressões faciais, e marcações não manuais de modo geral, pode constatar que elas carregam mais que aspectos linguístico-gramaticais. Caso os tradutores de Libras de textos sensíveis estejam profundamente preocupados em não contrariar as doutrinas estabelecidas a partir da interpretação da Bíblia sob o ponto de vista de sua religião, as expressões faciais não estarão ligadas somente a aspectos linguísticogramaticais mas também a aspectos ideológicos. Mesmo assim, a depender do contexto sócio-histórico-político, o sistema ideológico pode passar por mudanças. Por exemplo, apesar de Jerônimo, em um primeiro momento, ter sido considerado herege, mais tarde ele foi canonizado pela Igreja Católica, e sua tradução, antes ad referendum, a Vulgata, considerada um desserviço, passou a ser indispensável nas liturgias da Igreja. Mas o que explica essa mudança de concepção? O que justifica a alteração do epíteto "profano tradutor" para "tradutor santo", ou "santo tradutor"? O que trouxe a tradução e o tradutor da periferia para o centro das atenções?

Uma das maneiras pelas quais podemos reunir respostas é refletir sobre a dinâmica das relações dos "elementos" em um dado 
polissistema sociocultural, e é exatamente neste ponto do artigo que algumas ideias do professor israelense Itamar Even-Zohar, a respeito de polissistemas, vai servir como fundamento teórico para a compreensão de como o polissistema literário da cultura surda brasileira está estabelecendo repertórios, incluindo os de tradução. Para isso, passo a examinar a tradução da Bíblia para a Libras sob outra perspectiva: a perspectiva poética, i.e., literária. Mas, antes, é imprescindível apresentar brevemente alguns pressupostos teóricos sobre o entendimento de Polissistema.

\section{Breve comentário sobre o entendimento de polissistemas}

O entendimento de literatura como sistema, ventilado pelos formalistas russos, seria fonte da qual Even-Zohar não deixaria de beber, o que o ajudou a iniciar a resolução de problemas ligados tanto à história quanto à tradução da literatura vinculada a seu país. Com base na concepção de "sistema literário", advinda exatamente do Formalismo Russo, Even-Zohar (1990) elaborou e pavimentou um campo teórico que ficou conhecido como Teoria dos Polissistemas, nos anos 1970, mas, como o próprio Even-Zohar (1990, p. 1) destacou, "reformulada posteriormente e desenvolvida em um número de estudos que se seguiram [...]". Na base da teoria, o entendimento de que os fenômenos semióticos são mais bem compreendidos quando concebidos como sistemas dinamicamente constituídos por elementos inter-relacionados. Em suas próprias palavras:

[polissistema é] um sistema múltiplo, um sistema de vários sistemas que interagem uns com os outros e se sobrepõem parcialmente, usando opções simultaneamente diferentes, mas ainda funcionando como um todo estruturado, cujos membros são interdependentes. (EVEN-ZOHAR, 1990, p.11). 
Even-Zohar (1990) alicerçou suas postulações no que denominou de "funcionalismo dinâmico". Agora, manifestações semióticas como cultura, língua, pintura, literatura etc. passaram a ser compreendidas como partes de um todo em constante dinamismo e relação. Com essa linha de raciocínio fecundada, não tinha como a literatura traduzida não ser vislumbrada como um polissistema repleto de dinamismo em sua composição, um polissistema com modelos próprios. Aliás, sobre esta concepção - o de a literatura traduzida possuir modelos próprios - Lambert (2011, p. 200) aponta dois argumentos pelos quais Even-Zohar (1978) defende essa hipótese:

1) o fato de que uma determinada literatura aplica seus próprios princípios de seleção, mesmo diante de literaturas e obras estrangeiras bastante diferentes da sua (toda a Europa do século 18 uniu o destino de Ossian ao de Homero); 2) o fato de a literatura de chegada seguir uma certa estratégia em seu método de traduzir, mesmo diante de literaturas e obras estrangeiras bastante diferentes da sua.

Lambert (2011, pp. 200 e 201) complementa destacando que um ponto crucial é situar as traduções "dentro e em relação ao sistema literário, não apenas supor que elas funcionem como uma organização". Logo em seguida, realça duas perguntas: [as traduções] "são tradicionais ou inovadoras, e em que medida? Ocupam um lugar central ou marginal na vida literária?”. 


\section{O polissistema literário da cultura surda e as contribuições dos repertórios de tradução}

\subsection{O jovem sistema literário da cultura surda e seus repertórios}

Observando pelo mesmo ângulo de Even-Zohar (1990), e levando em consideração as reflexões propostas por Lambert (2011), podemos agora pensar a literatura surda situada em um amplo polissistema, no qual mantém relação com outros.

Ilustração 1 - Esquema de uma pequena parte do polissistema sociocultural brasileiro.

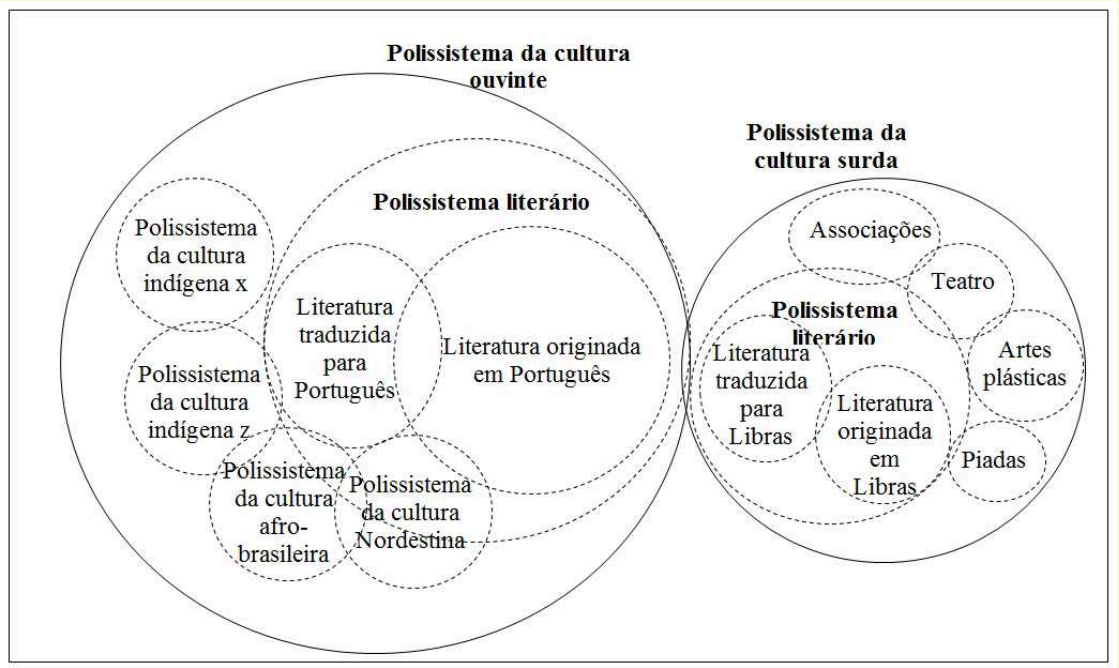

Fonte: Elaborada pelo autor.

Com base na ilustração, as relações estão representadas pelas interseções entre os conjuntos, já os polissistemas literários estão destacados (em maior grau), quando comparado com os outros, porque são eles os objetos de estudo deste trabalho, e não significa dizer que são os mais evidentes dentro do polissistema sociocultural brasileiro. 
De toda forma, embora ainda não se tenha uma descrição detalhada do polissistema literário da cultura surda brasileira, nem um mapeamento de seus poemas, isso não quer dizer que a literatura surda não exista, porque ela não só existe como já deu importantes passos. Por isso mesmo iniciar uma análise dos poemas em língua de sinais pode nos ajudar a compreender como se constituem os modelos de seleção e como os repertórios, incluindo os de tradução, estão solidificando a literatura surda. A propósito, algo semelhante aconteceu com o sistema literário hebraico, porque um pouco antes de formular suas hipóteses e dar contornos vastos à sua teoria Even-Zohar (1970) havia se deparado com a difícil tarefa de solucionar o "problema" da "intricada estrutura histórica" da literatura hebraica.

Também é possível perceber, na ilustração, duas culturas em destaque: a surda e a ouvinte. Os surdos compartilham da cultura de seu país, por isso são tidos como biculturais. No entanto, em virtude de experiências particulares corporais harmonizadas pela surdez, que aqui é entendida não como patologia, mas como agente de idiossincrasia e responsável por originar culturas surdas em várias partes do mundo, os surdos possuem uma teia de significâncias muito particular. Por meio dela, os surdos dividem entre si um conjunto de conhecimentos e interesses circunscritos em um código simbólico, transmitido e interpretado por seus pares. Por essa razão os percebo como membros de uma cultura própria, a cultura surda, na qual encontramos uma literatura de igual modo peculiar, também alicerçada em experiências especiais com o mundo. Esse é um dos motivos pelos quais este trabalho faz distinção entre "literatura ouvinte" e "literatura surda".

É importante destacar que literatura surda e literatura ouvinte não estão isoladas no polissistema, i.e., em virtude do contato especial entre cultura ouvinte e cultura surda e entre Libras e língua portuguesa, é natural uma especial relação entre as literaturas. Mas, nessa relação, a literatura surda recebe mais influência de repertórios da literatura ouvinte do que o contrário. Primeiro porque a ouvinte assume uma posição central no polissistema sociocultural do Brasil, depois porque os tradutores de Libras constantemente 
estão traduzindo poemas de poetas ouvintes para a literatura surda, não de poetas surdos para a literatura ouvinte. Aliás, a prática desta última possibilidade poderia não só contribuir com a difusão da cultura surda como um todo mas inovar o polissistema literário ouvinte. Entre os poetas ouvintes nacionais e internacionais mais traduzidos para a literatura surda estão Carlos Drummond de Andrade, Castro Alves, Cecília Meireles, Clarice Lispector, Conceição Evaristo, Cora Coralina, Edgar Allan Poe, Elisa Lucinda, Ferreira Gullar, Fernando Pessoa, Gonçalves Dias, Mário Quintana, Octavio Paz, Patativa do Assaré, Ruth Rocha, Vinícius de Moraes e William Shakespeare.

A partir dessas observações, não há com não compreender o tradutor de Libras como um dos elementos desse sistema, fornecendo importantes contribuições para a formação e consolidação em várias áreas, especialmente a da literatura. Por isso mesmo, em suas tomadas de decisões na tradução, (I) ele pode tanto ser influenciado pelos repertórios já estabelecidos e gerar traduções tradicionais, quanto (II) quebrar a régua do cânon e oferecer novos estilos, formas, ritmos, gêneros etc., usando recursos linguísticos e extralinguísticos diversos. No primeiro caso, a língua-alvo é quem determina a aplicação dos princípios de seleção, ou seja, são os repertórios já estabelecidos pelos poemas originados em Libras e pelas traduções mais tradicionais que acarretam as negociações linguísticas e culturais. No segundo caso, os princípios de seleção partem de fontes diversas, das quais cito: a língua-fonte, estratégias inovadoras, estratégias já usadas por tradutores de línguas oral-auditivas e de outras línguas de sinais.

Se traduções inovadoras em Libras serão aceitas pela tradição, não é possível prever, mas, pelo prisma da Teoria dos Polissistemas, é possível dizer que elas assumirão sim um lugar no sistema literário. Mas qual lugar? No centro ou na periferia? E qual a relação delas com o sistema? Na verdade, Even-Zohar (1990) observou que a literatura traduzida tende a ocupar uma posição mais periférica no polissistema, enquanto a literatura originada na língua nacional ou majoritária ocupa a posição mais central. Mas ele tam- 
bém notou três casos pelos quais a literatura traduzida pode assumir a posição central: (I) quando o sistema literário ainda é muito jovem, momento em que a tradução introduz novos repertórios (estéticas, estilos, formas, gêneros, ideias, linguagens etc.); (II) quando a literatura é considerada fraca, diante de outra literatura; e (III) quando uma literatura está em crise e ultrapassada, mas a tradução desempenha o papel de inová-la.

Das três, a hipótese (I) pode ser decisiva na explicação e na compreensão de novos repertórios que surgem no sistema literário da cultura surda. Por exemplo, atualmente, a literatura surda brasileira vem presenciando o surgimento do slam poetry, ou poesia slam, em seu polissistema literário. O termo slam tem o significado aproximado de "grande ruído", "grande barulho" ou mesmo "forte batida", e no contexto em que o termo "poesia slam" é usado, podemos compreendê-lo como "forte barulho de poesias" ou "batalha de poesias agitadas". De todo modo, o que antes pertencia somente à literatura ouvinte, agora passa a fazer parte da literatura surda. E o mais curioso é que, nas batalhas, a tradução está situada entre Libras e língua portuguesa, ela ganha lugar de destaque, dado que a declamação dos poemas é realizada por uma dupla composta por um surdo e por um ouvinte, que usam a Libras e a língua portuguesa. Esse novo gênero na literatura surda introduz novos repertórios de sinalização, tais como expressões faciais muito mais intensificadas, performance corporal agitada, combinação de língua oral-auditiva com língua de sinais, mistura de mímicas e gestos com o léxico das línguas de sinais, liberdade formal e ritmo muito mais acelerado. Em um contraste, na tradução de Cântico o ritmo é coordenado, lento e repetitivo, mas na poesia slam em língua de sinais, o mais comum é que o ritmo seja muito mais intenso, forte e variável.

Observe que a tradução vem desempenhando papel central no surgimento desse novo gênero no polissistema literário da cultura surda brasileira. Na verdade, em suas maiores contribuições, além de imortalizar obras e autores em diversos sistemas literários, as traduções também podem promover grandes impactos e mudanças 
na literatura de chagada, importando, inovando e criando repertórios. Um exemplo mais concreto sobre o assunto é destacado em Bassnett (2014, p. 21-22), quando cita o caso do:

Soneto Renascentista [...], uma forma popularizada na Itália pelo poeta Petrarca, que se espalhou rapidamente por uma grande variedade de línguas europeias como resultado de traduções a partir do original italiano, e atingiu o status canônico na maioria das literaturas ocidentais.

Em casos como esses, as traduções ocuparam uma posição central no cânone literário, e os tradutores exercem papel capital no processo de reorganização centro-periferia dos polissistemas. Assim, novas formas de rimas em Libras podem surgir, novos elementos extralinguísticos (incluindo sons, dado que a comunidade surda também é composta por ouvintes), novos jogos de linguagem, novos estilos de sinalização etc.

\subsection{Classificadores e morfismos como princípios de seleção da literatura surda}

Na tradução de Cântico para Libras realizado pelas TJ, os principais princípios de seleção seguem repertórios já estabelecidos pela literatura de chegada, i.e., pela literatura surda, principalmente no que diz respeito à exploração dos classificadores. Para citar um exemplo, trago aqui a figura de linguagem mais comum no poema: a comparação, por ser um dos ambientes linguísticos mais propícios para a eclosão dos classificadores nas traduções para Libras, especialmente os descritivos. Nas comparações em Cântico, o nome é como óleo aromático, a beleza é como panos das tendas de Salomão e como éguas dos carros do faraó, os olhos são equiparados aos das pombas, os dentes como rebanhos de ovelhas recém-tosquiadas, os seios são análogos a filhotes gêmeos de uma gazela que pastam entre os lírios, as faces são assemelhadas a dois 
pedaços de romãs, a língua como leite e mel etc. Mas a tradução de Cântico 4:1 é especialmente interessante para comentar, porque possibilitou a emergência de um efeito estético notavelmente poético na tradução para Libras, por meio de classificadores e morfismos. Em resumo, este último fenômeno pode ser compreendido como a convergência de parâmetros dos sinais realizados subsequentemente. Dito de outro modo: morfismo é o ponto onde duas (ou mais) partes de sinais subsequentes fundem-se.

Ao traduzir o trecho "Seu cabelo é como um rebanho de cabras Que descem as montanhas de Gileade." (Ct. 4:1), o tradutor explora os classificadores e os morfismos de forma muito criativa, peculiar e poética. Comentando primeiramente os classificadores, a partir de uma pequena seleção do verso em Libras, temos as seguintes sentenças : (I) "seus cabelos ondulados descem sobre seus ombros até chegarem aos seus bustos." (II) "Que lindo! Iguais às cabras que vão descendo as montanhas de Gileade" (III) "são seus cabelos ondulados descendo sobre seus ombros até chegarem aos seus bustos. Que lindo!".

Acima, há dois classificadores beneficiando a linguagem poética na tradução: o próprio corpo (figura 1.a) e a configuração de mãos. A tradução utiliza o corpo do tradutor como analogia entre "corpo da sulamita" e "montanhas de Gileade", e a configuração de mãos como comparação dos "cabelos da sulamita descendo sobre o corpo" (figura 1.a) com as "cabras descendo as montanhas de Gileade" (figura 1.b). O espaço do lado esquerdo do tradutor (figura 1.b) é usado para descrever as montanhas de Gileade, e o espaço onde o tradutor está evidencia a presença da personagem sulamita, descrevendo o corpo dela quando explora o classificador "cabelos ondulados descendo sobre seus ombros até chegarem aos seus bustos". Ao fazer isso, o efeito poético dá ao espectador a impressão de que "corpo da sulamita" e "montanhas de Gileade" são amalgamados. Observe que, enquanto na figura 1.a são os cabelos ondulados que vão descendo o corpo da sulamita, na figura 1.b são as cabras que vão descendo as montanhas de Gileade. Nesse sentido, os classificadores "corpo da sulamita" e "montanhas de 
Gileade" são correspondentes poéticos, ou seja, "corpo de sulamita" é semelhante às "montanhas de Gileade", enquanto os classificadores "cabelos ondulados" e "cabras" também geram essa relação poética.

Figura 1 - Classificadores.

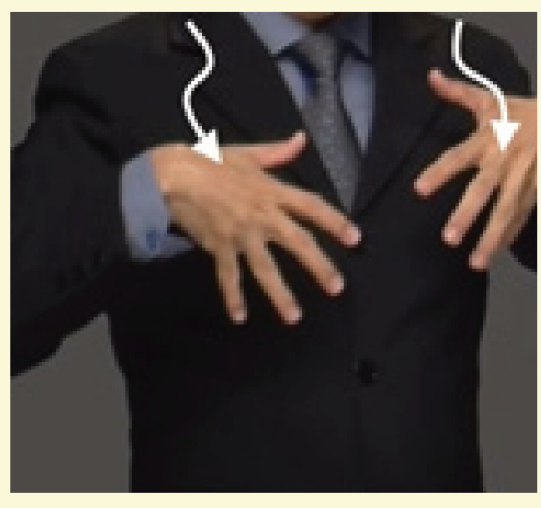

Figura 1.a - Classificador para corpo e cabelos

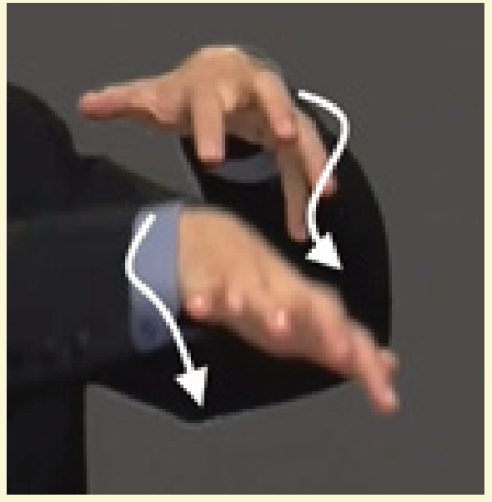

Figura 1.b - Classificador para "cabras"

Fonte: Elaborada pelo autor.

Já o efeito poético proporcionado pelo morfismo surge do aproveitamento de parâmetros do ponto de encontro do classificador (I) "seus cabelos ondulados" com o classificador (II) "descem sobre seus ombros até chegarem aos seus bustos" e com o sinal lexical "Que lindo!". O outro morfismo poético surge do aproveitamento do mesmo parâmetro "Configuração de Mãos", mas, desta vez, quando o tradutor explora o ponto de encontro entre "cabras que vão descendo as montanhas de Gileade" e a própria descrição da montanha.

Em várias partes de Cântico dos Cânticos é possível perceber o uso de uma linguagem bastante sensual. Na verdade, dependendo da interpretação, uma linguagem que muito se aproxima do erótico. Por exemplo, a leitura do trecho abaixo retirado dos versos 2, 3, 7 e 8 do capítulo 4 pode sugerir algumas interpreta- 
ções eróticas. Ora, se o eu lírico compara o umbigo de sua amada a uma taça de vinho, o ventre a um monte de trigo cercado de lírios, os seios a cachos de uva, uma das inferências do leitor é aquela que o leva a interpretar que o casal não possui tabus com relação a utilizar diversas partes de seu corpo para sentir e proporcionar prazer um ao outro.

Seu umbigo é uma taça redonda

Em que nunca falta vinho misturado.

Seu ventre é um monte de trigo,

Cercado de lírios.

Seus seios são como dois filhotes de cervo,

Crias gêmeas de uma gazela

[...]

E seus seios são como cachos de tâmaras.

Eu disse: 'Subirei na palmeira,

Para pegar os seus frutos.

Sejam os seus seios como cachos de uva;

[...]

No entanto, se no texto-fonte o formato dos seios da personagem feminina fica a critério de quem faz a leitura, no texto-alvo as dimensões proeminentes e acentuadas pelo classificador realçam mais ainda os seios, tornando a linguagem da tradução muito mais sensual aos espectadores. Isso porque, com o uso do classificador, os seios ganham volume destacado e um vasto contorno. 
Figura 2 - Classificador para descrever os seios da Sulamita

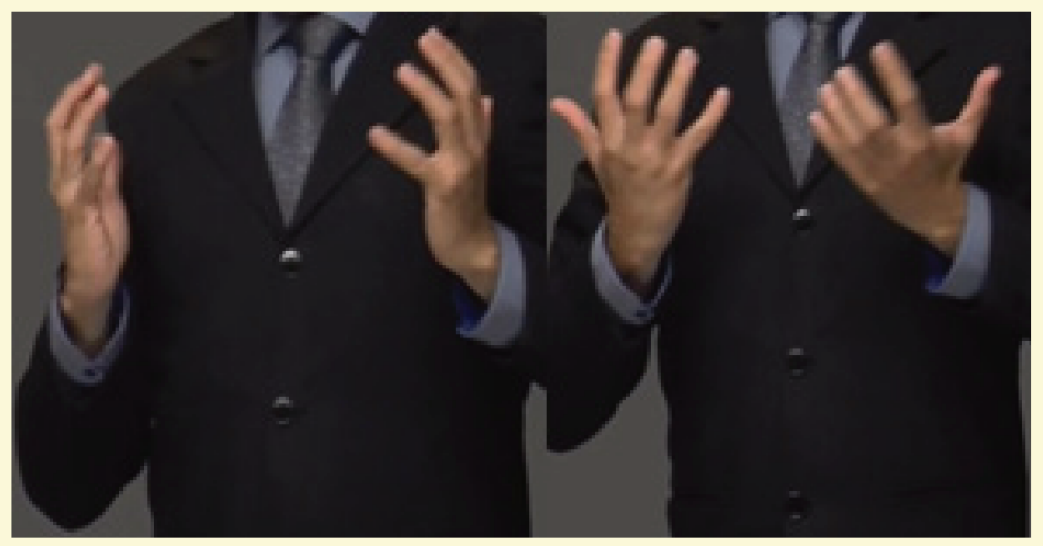

Fonte: Elaborada pelo autor

\subsection{Expressões faciais, explicitação e ideologia no polissistema literário}

Cântico dos Cânticos é concebido e lido como um livro alegórico pelas religiões judaico-cristãs. Os judeus, por um lado, concebem a linguagem como uma alegoria histórica do relacionamento entre Deus e o povo de Israel; os cristãos, por outro, compreendem-na como uma alegoria escatológica do relacionamento entre Cristo (conceitualizado como noivo) e a Igreja (conceitualizada como noiva). Destaco essas informações porque, diante dessas particularidades, é possível que as traduções sejam dotadas de ideologias dogmático-religiosas, mesmo na presença do lirismo substancial de Cântico. Por exemplo, na seção 1 apontei que as expressões faciais de tradutores de Libras carregam muito mais que informações linguístico-gramaticais, e que isso ocorre em virtude de leis implícitas ligadas a ideologias ou a tradições dogmáticas. Outra expressão facial com essas características encontra-se na tradução de Cântico 1:4. O fragmento em língua portuguesa diz o seguinte: 
Leve-me com você, e corramos.

O rei me trouxe ao seu aposento reservado!

Alegremo-nos e exultemos juntos.

Celebremos suas expressões de amor, que são melhores do que o vinho.

É com razão que elas o amam!

Antes de comentar parte da tradução, convém informar que, em Cântico, alguns veem duas personagens principais: a camponesa sulamita e o rei Salomão. Por essa óptica, todo o poema é uma sucessão de monólogos metafóricos sobre o amor entre ambos, ou seja, a bela camponesa e o rei, por meio de seus discursos, expressam seus mais profundos sentimentos de amor. Mas há outros que veem mais uma personagem principal: um jovem pastor de ovelhas. É o caso das TJ. Para eles, e para tantos outros que defendem essa tese, as juras de amor não acontecem entre Salomão e a sulamita, mas entre esta e um jovem pastor de ovelhas. $\mathrm{Na}$ verdade, o rei Salomão, também apaixonado pela jovem, leva-a até seu palácio e tenta conquistá-la, assediando-a de várias formas. No entanto, ela não cede aos cortejos do rei e recusa todas as ofertas, sendo fiel e guardando seus carinhos e seu amor para o pastor de ovelhas, por quem é apaixonada e de quem é namorada. Com esse enredo, a interpretação alegórica entende a sulamita como a Igreja, o pastor de ovelhas como Jesus e o rei Salomão como Satanás.

Em virtude dos versos anteriores, ao iniciar a tradução do trecho acima para a Libras, o tradutor já está assumindo a fala da jovem sulamita. Para que isso fique claro aos espectadores, ele deixa seu corpo e seu olhar levemente voltado para seu lado direito enquanto sinaliza. Dessa forma, a sinalização produzida a partir dessa orientação corresponde ao discurso da sulamita, que é direcionado a alguma personagem no espaço neutro do lado direito. Ao traduzir a linha dois do trecho acima, o tradutor não só aponta e olha para o espaço neutro do seu lado esquerdo, fazendo surgir a terceira personagem (o rei Salomão), mas também utiliza uma expressão facial que denota descontentamento, sugerindo ao 
espectador o antagonismo do rei Salomão, o obstáculo que tentando burlar o relacionamento entre ela e o pastor de ovelhas, seu verdadeiro amor.

A expressão facial acima é responsável pela explicitação. Porém, minha alegação é a de que essa explicitação não é proveniente do enunciado do texto-fonte em si, mas do conjunto de leis estabelecidas pela ideologia dogmático-religiosa. Ou seja, do trecho em língua portuguesa não é possível extrair o antagonismo do rei Salomão, aliás, nem mesmo a presença do pastor como terceira personagem, mas na tradução isso é evidente por meio da expressão facial. Ora, sem a presença do rei Salomão como antagonista, a interpretação alegórica das três personagens desapareceria: a sulamita como a Igreja, o pastor de ovelhas como Jesus e o rei Salomão como Satanás. É, portanto, o cuidado em cumprir com leis implícitas o responsável por provocar essa explicitação, gerando repertórios específicos na literatura traduzida de um dado polissistema.

Como dito anteriormente, as explicitações mencionadas neste artigo são provenientes de leis implícitas em um conjunto de concepções ideológicas que regem as atividades comunicativas e tradutórias de um determinado grupo, neste caso específico, as TJ. Ao constatamos essas explicitações, percebemos que até mesmo os repertórios de tradução de textos sensíveis possuem certa independência em relação ao texto-fonte, mas indicam possuir uma dependência forte com as ideologias. Usando uma metáfora: ideologia é a mão invisível que controla as mãos de boa parte dos tradutores. Expandindo essa metáfora para o tradutor de Libras, ela controla não apenas as mãos mas também todo o corpo, incluindo as expressões faciais, porque em línguas de sinais, há casos em que elas revelam muito mais que aspectos gramaticais.

\subsection{O poema em prosa como um dos repertórios da literatura surda}

Antes de finalizar as reflexões sobre o jovem polissistema literário da cultura surda neste artigo, é preciso dizer que mesmo exis- 
tindo uma relação entre literatura ouvinte e literatura surda, esta última possui seus próprios princípios de seleção. Por exemplo, quem assiste aos poemas "O voo do Rio a Florianópolis ${ }^{10 ", ~ " F i v e ~}$ Senses" $" 11$ "Dew on Spiderweb" ${ }^{12}$, da poetisa surda brasileira Fernanda Machado, do poeta surdo britânico Paul Scott e da poetisa surda americana Ella Lentz, respectivamente, logo percebe algumas características muito peculiares: (I) uma exposição bem desenvolvida a partir do uso de muitos classificadores; (II) a presença de personagens antropomórficas; (III) morfismos; (IV) contornos narrativos e (V) brevidade estrutural. Na verdade, no poema Dew on Spiderweb, embora não se tenha a presença de personagens, ele apresenta todas as outras quatro características. O fato é que essas características em conexão com a liberdade formal dos versos e das estrofes dessas produções geram uma convergência entre poesia e prosa, fazendo surgir o poema em prosa no sistema literário da cultura surda - pelo menos sob minha perspectiva.

Paixão (2013, p. 152), um dos mais importantes pesquisadores sobre poema em prosa, destaca que, à primeira vista, "não é fácil compreender a natureza desse gênero, porque ele pode ser facilmente confundido com outro: a prosa poética". Para distinguir um do outro, o pesquisador sublinha uma questão semântica, impulsionada pelas primeiras palavras dos termos "prosa poética" e "poema em prosa", ou seja, a ênfase recai nas palavras iniciais. Embora repleta de lirismo, de metáforas e outros recursos próprios da poesia, a principal característica da prosa poética é o prolongamento textual, e mesmo usando recursos da poesia, estes, conforme observa Paixão (2013, p. 152), estão subordinados aos ritmos dos discursos mais longos. Para citar exemplos de prosa poética, o autor menciona as obras Finnegans Wake, de James Joyce; Grande Sertão Veredas, de João Guimarães Rosa; e Lavoura arcaica, de Raduan Nassar. Essas três obras não abriram mão do plano exten-

\footnotetext{
${ }^{10}$ Machado (2013)

${ }^{11}$ Scott (2013)

${ }^{12}$ Lentz (2010)
} 
sivo, narrativo, aventureiro, de múltiplas possibilidades finais e, a cima de tudo, do plano prosaico, mas também não dispensaram a linguagem poética.

Baseando-se no impulso semântico da primeira palavra (poema), e nas postulações de Decaunes (1984), Paixão (2013, p. 153) destaca que o poema em prosa, por sua vez:

desentranha-se da ideia de poema. É a partir do impulso poético que o seu conteúdo ganha forma e unidade. Seja composto de cinco linhas ou de duas páginas, cada poema deve forjar o tema e os recursos de sua proposição. Ao desfrutar de liberdade formal, defronta-se com um horizonte de possibilidades mil para a expressão, mas reguladas pelo desafio da concisão. Pode até mesmo recorrer à descrição ou à narração de algum fato ou ocorrência diária, mas de maneira breve e elíptica.

Em Quintana (2012) podemos nos deparar com uma série de poemas em prosa, dos quais cito "Paisagem de após-chuva, Só para si, Feliz, Janela de abril, Viração, Sinais dos tempos, O poema, A adolescente, Gare, Aventura no parque, Passarinho empalhado" etc. Dentre estes, quero trazer os dois últimos, começando por "Passarinho empalhado":

Quem te empoleira lá no alto do chapéu do contravó, tico-tico surubico? Tão triste... tão feio... tão só... Meu tico-tiquinho coberto de pó... E tu que querias fazer o teu ninho na máquina do Giovanni fotógrafo! (QUINTANA, 2012, [s.p.]).

Neste poema escrito em prosa, o autor transforma uma pequena e singela cena do dia a dia em uma linguagem poética, deixando patente o impulso poético de que tanto falam Decaunes (1984) e Paixão (2013). O mesmo ocorre com "Aventura no parque": 
No banco verde do parque, onde eu lia distraidamente o Almanaque Bertrand, aquela sentença pegou-me de surpresa: 'Colhe o momento que passa.' Colhi-o, atarantado. Era um não sei que, um flapt, um inquietante animalzinho, todo asas e todo patas: ardia como uma brasa, trepidava como um motor, dava uma angustiosa sensação de véspera de desabamento. Não pude mais. Arremessei-o contra as pedras, onde foi logo esmigalhado pelo vertiginoso velocípede de um meninozinho vestido à marinheira. 'Quem monta num tigre (dizia, à página seguinte, um provérbio chinês), quem monta num tigre não pode apear'. (QUINTANA, 2012, [s.p.])

Partindo dessas observações, e comparando essas produções poéticas em língua portuguesa com as produções poéticas em línguas de sinais, citadas aqui, minha principal alegação é a de que o poema em prosa tem sido um gênero comum no polissistema literário da cultura surda. Nos poemas "O voo do Rio a Florianópolis", "Five Senses" e "Dew on Spiderweb", o princípio de seleção voltou-se para esse gênero, pelos vestígios narrativos, pela liberdade formal dos versos e das estrofes na sinalização que dissipa sua obrigatoriedade, pelo impulso poético que surge da ideia de poema, não da ideia de prosa, e pela concisão.

\section{Conclusão}

Os surdos não precisam desejar possuir uma literatura, porque eles já construíram a sua e estão ampliando-a e consolidando-a. No entanto, ao compararmos o polissistema literário da cultura ouvinte com o da cultura surda, sem dúvidas, o primeiro assume lugar central. Um dos motivos está ligado ao empenho de muitos poetas, leitores, tradutores, pesquisadores e estudiosos ao longo dos anos. Por meio deles, o sistema literário da cultura ouvinte ramificou-se sobremaneira e acumulou vários repertórios, formando bases bem definidas e um arcabouço poético bastante expressivo. Infelizmente 
a literatura surda brasileira ainda não possui um acumulado tão expressivo de poemas, poetas, leitores, tradutores, pesquisadores e estudiosos, e isso também dificulta as pesquisas e as reflexões sobre esse jovem sistema literário.

Os poemas em línguas de sinais são registrados, principalmente, em vídeos, e os registros só foram possíveis com o avanço da tecnologia, sobretudo com a popularização de aparelhos de captura de vídeos (especialmente smartphones), por isso muita coisa do polissistema da cultura surda foi perdida, embora outras tenham sido mantidas pela transmissão de material cultural via sinais, legado de geração a geração pelos surdos. Mas de forma nenhuma isso torna a literatura surda inexistente ou menos importante, a não ser pelo tratamento que o sistema literário brasileiro como um todo tem lhe dado. O que falta mesmo é reconhecimento e valorização, além de uma descrição detalhada de suas características, em seus vários estágios, seus repertórios de tradução, seus princípios de seleção etc.

Com relação ao que falei sobre encurralamentos tradutórios e ideologias dogmático-religiosas no artigo, verdade seja dita, a prerrogativa de desafiar o tradutor ou de tentar condicioná-lo à submissão de caprichos não é exclusividade dos textos literários, porque os textos sensíveis não precisam disputar ou reclamar esse direito, dado que eles também são carregados de especificidades, e boa parte delas está na ideologia dogmático-religiosa. Por meio dela, o texto sensível sempre tenta se agigantar e, ao mesmo tempo, diminuir a figura do tradutor, tentando transformá-lo em um mero observador inocente, ou em um ingênuo amador curioso, caso sua ideologia seja incompatível com a do grupo a espera da tradução. À vista disso, além de lidar com as nuanças estritamente textuais, o tradutor bíblico precisa lidar com ideologias, pelas quais as negociações e as relações entre texto-fonte e texto-alvo precisam ser condicionadas aos dogmas religiosos.

$\mathrm{Na}$ tradução literária, utilizando o conceito de transcriação de Campos (1992), se traduzir é recriar, então me parece substancial que o tradutor reivindique no mínimo o seu protagonismo autoral no texto-alvo, que persistirá mesmo após a caducidade de sua tra- 
dução. E como o tradutor não pode (nem deve desejar) furtar-se da crítica literário-tradutória, suas tomadas de decisões e as evidências de que sua atuação também foi poético-artística devem ser sua melhor militância, respeitando a correspondência entre ambos os textos. Daí vem o entendimento de poeta-tradutor. A propósito, seu certificado de poeta-tradutor pode surgir não só de sua autoria na tradução, mas também da notária crítica literário-tradutória. Perceba, então, que, aqui, temos três pontos importantes fazendo frente e somando forças com o tradutor: a autoria, a linguagem artístico-poética na tradução e o alto grau de correspondência entre texto-fonte e texto-alvo. Dessa forma, percebemos que sozinho o tradutor pode ser vencido pelos encurralamentos tradutórios, mas se um cordão de três dobras é mais difícil de arrebentar, imagina, então, um de quatro dobras.

Já na tradução da Bíblia, a reivindicação autoral do tradutor, a recriação, pode parecer uma divagação, ou água além da conta para Narciso dar de conta, uma vez que o "Autor-primeiro" não divide sua glória com ninguém, pelo menos no entendimento dogmático-religioso.

\section{Referências}

BASSNETT, S. Translation: the new critical idiom. Londres; New York: Routledge, 2014.

BÍBLIA. Bíblia Sagrada Edição Pastoral. São Paulo: Pia Sociedade de São Paulo: PAULUS, 2002.

BÍBLIA. Libras. Bíblia em American Sign Language. Cesário Lange: Associação Torre de Vigia de Bíblias e Tratados, 2015. Disponível em: < https://www. jw.org/ase/ > . Acesso em: 10 out. 2017. 
BÍBLIA. Libras. Bíblia em Lengua de Señas Argentina. Cesário Lange: Associação Torre de Vigia de Bíblias e Tratados, 2015. Disponível em: < https:// www.jw.org/aed/ > . Acesso em: 10 out. 2017.

BÍBLIA. Libras. Bíblia em Língua Brasileira de Sinais. Cesário Lange: Associação Torre de Vigia de Bíblias e Tratados, 2015. Disponível em: < https:// www.jw.org/bzs/ > . Acesso em: 10 out. 2017.

BÍBLIA. Português. Bíblia de referências Thompson. Edição Contemporânea. Tradução de João Ferreira de Almeida. Brasília: Sociedade Bíblica do Brasil, 1995.

BÍBLIA. Tradução do Novo Mundo da Bíblia Sagrada. Cesário Lange: Associação Torre de Vigia de Bíblias e Tratados, 2015.

CAMPOS, H. Bere'shith: a cena da origem. São Paulo: Perspectiva, 2000.

CAMPOS, H. Metalinguagem e outras metas: ensaios de teoria e crítica literária. São Paulo: Perspectiva, 1992.

CAMPOS, H. Qohélet: O-que-sabe. 2. ed. São Paulo: Perspectiva, 2004.

DECAUNES, L. Le Poème en prose: anthologie. Paris, Seghers, 1984.

DEW on Spiderweb. Performance de: Ella Mae Lentz. Berkeley, Califórnia, 1'20'. 2010, vídeo. Disponível em: < https://youtu.be/YaHChvFWegQ>. Acesso em: 20 nov. 2017.

EVEN-ZOHAR, I. Papers in Historical Poetics. Tel Aviv: Porter Institute, 1978. . Polysystem studies. Durham NC: Duke University Press, 1990.

. The Nature and Functionalization of the Language of the Literature under Diglossia. Tel Aviv: Hasifrut, 1970.

FIVE Senses. Produção: XI Congresso Internacional da ABRAPT e V Congresso Internacional de Tradutores. Performance de: Paul Scott. Florianópolis, 
Santa Catarina. 16'29'. 2013, vídeo. Disponível em: < https://youtu.be/Ds_ mv8YVkME >. Acesso em: 20 nov. 2017.

GRICE, H.P. Logic and Conversation. In: COLE, P; MORGAN, J. (Eds). Syntax and Semantics. v. 3. New York: Academic Press, 1975. p. 41-58.

LAMBERT, J. A tradução. Tradução de Marie-Hélène Catherine Torres e Álvaro Faleiros. In: COSTA, W.; GUERINI, A.; TORRES, M. H. C. (Org.). Literatura e tradução. Textos selecionados de José Lambert. Rio de Janeiro: 7 letras, 2011. p. 183-2017.

LEFEVERE, A. Translation/History/Culture: A Sourcebook. London: Routledge, 1992.

LUTERO, M. Carta aberta sobre a tradução. Tradução de Mauri Furlan. In: HEIDERMANN, W. (Ed.). Clássicos da Teoria da Tradução. Antologia bilíngue (Alemão-Português). v. 2. Florianópolis: UFSC / Núcleo de Pesquisas em Literatura e Tradução, 2010. p. 95-115.

O VOO do Rio a Florianópolis. Produção: XI Congresso Internacional da ABRAPT e V Congresso Internacional de Tradutores. Performance de: Fernanda Machado. Florianópolis, Santa Catarina. 16'29'”. 2013, vídeo. Disponível em: <https://youtu.be/Ds_mv8YVkME >. Acesso em: 20 nov. 2017.

PAIXÃO, F. Poema em prosa: problemática (in)definição. Revista Brasileira. Riode Janeiro, n. 75, 2013, p. 151-162.

PERLIN, G. O lugar da cultura surda. In: THOMA, A.S.; LOPES, M. C. (Orgs.). A invenção da surdez: cultura, alteridade, identidade e diferença no campo da educação. Santa Cruz do Sul: EDUNISC, 2004, p. 73-82.

PERLIN, G. $O$ ser e o estar sendo surdos: alteridade, diferença e identidade. 2003. 78 f. Tese (Doutorado em Educação). Universidade Federal do Rio Grande do Sul, Porto Alegre, 2003. Disponível em: < http://www.lume.ufrgs.br/ bitstream/handle/10183/5880/000521539.pdf > . Acesso em: 18 nov. 2017.

QUINTANA, M. Canções seguido de Sapato florido e a Rua dos cataventos. Recurso eletrônico. Rio de Janeiro: Objetiva, 2012. 
ROBINSON, D. The Invisible Hands that Control Translation. Recurso eletrônico. Universitat Autònoma de Barcelona, Barcelona, 2009. Disponível em: < http:// pagines.uab.cat/seangolden/en/content/invisible-hands-control-translation $>$. Acesso em: 12 de nov. 2017.

STRÖBEL, Karin. As imagens do outro sobre a cultura surda. 3. ed. Florianópolis: Editora UFSC, 2013.

WILSON, D; SPERBER, D. Outline of relevance theory. Topics in Linguistics. Links \& Letters. Barcelona, v. 1. p. 85-106, 1994. Disponível em: <https:// www.raco.cat/index.php/LinksLetters/article/view/49815/87793>. Acesso em: 19 nov. 2017.

WILSON, D; SPERBER, D. Teoria da relevância. Linguagem em (Dis) curso. Tubarão, v. 5, n. esp., p. 221-268, 2005. Disponível em: <http:// www.portaldeperiodicos.unisul.br/index.php/Linguagem_Discurso/article/ view/287/301 > Acesso em: 19 nov. 2017.

Recebido em: $16 / 04 / 2018$

Aceito em: 07/07/2018

Publicado em setembro de 2018

Emerson Cristian Pereira dos Santos. E-mail: em.cristian@gmail.com ORCID: https://orcid.org/0000-0002-1665-9358 